\title{
The effects of Vygotsky's sociocultural theory on second language acquisition and language Input
}

\section{Efectos de la teoría sociocultural de Vygotsky en el aprendizaje de una segunda lengua y aporte lingüístico}

\author{
Leidy Johanna Villamizar Castrillón \\ Master in Education from University of Alabama, USA. \\ Currently teaching English and member of the Foreign \\ Language Proficiency Team \& Internationalization \\ Department at Universidad Santo Tomas de Aquino, \\ Floridablanca, Colombia \\ Correo electrónico: leidyvc@gmail.com
}

\section{Cómo citar este artículo:}

Villamizar, L.J. (2017). Efectos de la teoría sociocultural de Vygotsky en el aprendizaje de una segunda lengua y aporte lingüístico. Espiral, Revista de Docencia e Investigación, 7(1), 91 - 102.

\begin{abstract}
Objective. The present reflection article derives from a Diploma Course on Updating Teaching English Practices with Emphasis on Designing Learning Experiences, which took place at Universidad Industrial de Santander, Colombia. It is aimed at reflecting upon the key role of comprehensible input and social interactions between second language learners, teachers, peers and a meaningful learning environment. In addition, a revolutionary teaching model called SIOP for English learners will be described in terms of definition, justification and application to the classroom.
\end{abstract}

Methodology. This paper is framed within a documentary research that, from a hermeneutic perspective, makes reference not only to the methodology, assignments and resources used for second language acquisition in a formal academic setting, but also to the suitable language input students should be encountered with to reach higher order thinking processes and develop outstanding communicative skills. The results of this conceptual analysis, focused on the Sociocultural Theory elaborated by the psychologist Lev Vygotsky, have allowed us to examine how a second language is learned successfuIly if teachers are able to manipulate input through effective scaffolding techniques which are thought to offer support to each student throughout the learning process until they can progressively get rid of it.

Results. The impact of the Socio-cultural Theory by Vygotsky on second language acquisition leads us to suggest the SIOP as a new approach towards English teaching. This emphasizes the use of comprehensible input that is highly beyond students' level of competence and multiple interactions at all levels throughout the lesson from the preparation and delivery to the assessment stage.

Keywords: Higher order thinking skills, Input, Scaffolding, second language acquisition, interaction, SIOP.

\section{Resumen}

Objetivo. El presente artículo de reflexión se deriva del Diplomado en Actualización de Prácticas de Enseñanza del Inglés con énfasis en el Diseño de Experiencias de Aprendizaje, el cual tuvo lugar en la Universidad Industrial de Santander, Colombia. Tiene como objetivo suscitar una reflexión acerca del papel fundamental del input comprensible y las interacciones sociales entre los estudiantes de una segunda lengua, docentes y compañeros en un espacio de aprendizaje significativo. Adicionalmente, un modelo de enseñanza revolucionario llamado SIOP para estudiantes de inglés será descrito en términos de su definición, justificación y aplicación al aula de clase.

Metodología. El enfoque está enmarcado en la investigación documental que desde una visión hermenéutica hace referencia no solo a la metodología, tareas y recursos utilizados para la adquisición de una segunda lengua en un escenario académico formal, sino también al aporte lingüístico apropiado con el cual los aprendices deben interactuar con el fin de alcanzar procesos de pensamiento complejos y desarrollar habilidades comunicativas sobresalientes. Los resultados de esta profun- 
dización conceptual, enfocada en la teoría sociocultural elaborada por el sicólogo Lev Vygotsky, han permitido examinar cómo se aprende una segunda lengua exitosamente, si los docentes intentan manipular el input adecuadamente por medio de estrategias de soporte o andamiaje, las cuales están diseñadas para ofrecer apoyo a los estudiantes a lo largo de su proceso de aprendizaje hasta que puedan progresivamente deshacerse de ellas.

Resultados. Los aportes de la Teoría Sociocultural de Vygotsky en el aprendizaje de una segunda lengua llevan a sugerir el SIOP como un nuevo enfoque hacia la enseñanza del inglés. Esta estrategia se enfoca en el uso del input comprensible que está significativamente por encima del nivel de competencia de los estudiantes, así como en las múltiples interacciones a diferente nivel a lo largo de la clase, desde la preparación y la instrucción hasta la etapa de evaluación.

Palabras clave: Adquisición de una segunda lengua, estrategias de soporte, input, procesos de pensamiento, interacción, SIOP.

\section{Introduction}

Humans are essentially social beings. Since the time we are born, a variety of social interactions start to take place within our families, schools, communities and definitely, our own learning situations. As a natural process, learning is a complex and dynamic experience in which learners, teachers, peers and a specific environment interact between each other in order to gain higher mental functioning.

Multiple researchers on language learning have attempted to study how those social interactions can actually lead to successful Second Language Acquisition (hereinafter referred to as SLA). According to Vygotsky's Sociocultural Theory (1978) learning should always be closely related to what students already know (prior knowledge) and from there; teachers should start elaborating suitable experiences to achieve higher mental processes (Turuk, 2008). This is known as the Zone of Proximal Development (hereinafter referred to as ZPD) in which memorizing, thinking, paying attention, problem-solving and concept formation skills should be fostered. As Nguyen (2013) states the ZPD contains two basic components: first, there is always a task or a problem that needs to be solved with the help of someone else who is considered the expert on the matter; and second, there is also a person, often called novice, who can do better if well-assisted. Although there have been a number of controversies about what type of participant can be named as the "expert", more and more researchers believe that experts can be not only teachers or high achiever students, but also other peers, parents or administrators.

\section{The Role of Input in SLA}

Vygotsky assures that for learning to happen, both suitable input and output should be facilitated in explicit instruction. At this point, several discrepancies have arisen. Benati (2016) calls for a reflection upon the role of instruction in SLA and wonders if explicit teaching does really make a difference. He lists educators such as Krashen, author of the Natural Approach (1985) and the Input Hypothesis, who states that humans, whether they are embedded in a formal or non-formal educational setting, acquire a language by understanding messages that contain structures slightly beyond their level of competence. In other words, the more comprehensible input through listening and reading opportunities students face, the closer they are to SLA. Similarly, White insists on the irrelevance of direct language instruction, due to the fact that some language aspects are universal so there is no need for teacher directed lessons for SLA to happen. Pienemann \& Lenzing go beyond the idea of explicit instruction and assure that if used, it needs to consider the level of readiness students' show.

On the other hand, there have been other authors such as Van Patten who certainly have faith in direct instruction because they have examined the way second language learners process information and found out that they first focus on meaning (words) and later on forms (grammar). What this means is that tea- 
chers need to attempt to provide more explicit exposure to grammar aspects systematically, since these are not really acquired by solely contact with comprehensible input. Consequently, instruction is seen as an effective facilitator to reach native-like linguistic competence by trying to match the explicit knowledge suggested and the implicit mental representations shaped in students' minds. Among the techniques to manipulate a second language in order to make it more accessible to new learners, the input flood and the textual enhancement are highlighted as the most popular resources to modify a text with a specific item many times and provide typographical cues respectively (Benati, 2016).

In regard to comprehensible output, Swain (1995) claimed that output was actually more important than input in SLA, because it develops fluency, raises language awareness and generates immediate, constant feedback. Agreeing with Nowbakht (2015), second language learners need to move from semantic processing carried out when receptive skills are set into action, to syntactic processing in which the development of productive skills in SLA results paramount. In the light of the above premise, there are three major output functions in SLA: a) noticing the gap that describes the moment in which a student fails to produce a word or expression within a sentence in the target language; b) testing hypothesis that appears when the student tries to generalize rules because he is not sure whether his utterance is right or wrong so he decides to give it a try; and c) metalinguistic functions, which come up when the student reflects upon his own learning process, identifies strengths and weaknesses, and makes plans for language improvement. At this point, a new paradox appears: How can teachers know what the best input is? What kind of output should be expected from learners? Can they expose their students to input that is highly beyond their level of competence and still reach SLA?
As mentioned above by Vygotsky (1978), input and output are mutually dependant. Teachers cannot provide appropriate input if they have not analyzed their students' output first; and likewise, students cannot generate effective output if they have not received meaningful input. As a result, both are equally important in order to reach students' ZPD successfully. As a matter of fact, Navracsics (2014) declares that both the quality and quantity of comprehensible input configures students' second language proficiency levels and promotes the development of metacognitive skills since the target language is seen as a whole linguistic system. In order to acquire the language effectively, the author also advocates three different types of motivation: a) GLE - General Language Effort; $b$ ) LAE - Language Acquisition Effort; and c) LME - Language Maintenance Effort. All these three kinds appear to be vital not only in SLA but also in multilingual developmental settings, such as families raising multilingual children in an English speaking country. This is the case of a pair of Canadian siblings, whose mother spoke mainly Persian while her husband was not at home; although English was mostly spoken out of their house and in family interactions, this mom accidentally taught her kids certain expressions and forms in Persian, that ended up being crucial input when they moved to Hungary and had to communicate. What this implies is that what we learn implicitly is closely directed to our emotions and this is what ultimately becomes essential in life-long learning.

\section{Interaction as a cornerstone factor in SLA}

In addition to the importance of input experiences, what teachers should really bear in mind is how to make that input not too challenging, not too meaningless. Wood et al" (1976) stated that one way to adapt knowledge and learning environment for students' mental functioning is by using Scaffolding. This strategy refers to the adaptations and modifications 
input should undergo to be effectively understood, processed and acquired, helping learners temporarily become "self-interpreting cultural agents." As a result, if scaffolded input is provided as well as suitable guidance towards students' ZPD, SLA may still be reached, no matter how tough the input is. The truth is that for scaffolding to take place, a negotiation of meaning by two interlocutors at least needs to occur. Yi \& Sun (2013) describe this process as an interactional work to achieve mutual understanding when a problem appears, which seems to be a comprehensive definition for language communication. As suggested by Ellis (2005) and Long (1985), these clarification requests such as repetition, gestures, simpler language and slow talk, involve more interactions in SLA so the more negotiation second language learners have, the more chances they get to receive comprehensible input. This was evident in a research study conducted with 182 Chinese high school and college students, who participated by joining either a control group or an experimental group for an English as a second language intervention program. Yi \& Sun (2013) confirmed their assumption on negotiation of meaning, since the students who got more interactions improved second language vocabulary significantly.

Taking into consideration Vygotsky's SocioCultural Theory effects on SLA and the importance of interactions, several steps should be taken towards the implementation of a new possible teaching design. To start with, teachers should remarkably be familiar with students' past experiences; not only related to their academic background and performance, but also to their personal life events. To do so, a diagnosis test may be applied so teachers can create a clearer picture of what their students' ZPD is. After using this individual tool in order to identify strengths and weaknesses on students' higher mental functioning, teachers can move ahead to look for appealing materials that will best fulfill their needs. Although lear- ners might claim to feel sometimes lost or uncertain about language usage, teachers should be positive and keep searching for input that is highly beyond their level of competence. As the so-called proverb "Practice makes perfect" assures, the more you demand the better results you will gain.

Secondly, teachers should be careful and creative to get the best benefits of the previously chosen input to be used in class. High quality materials can be totally meaningless if they are not manipulated accordingly to reach students' ZPD and encourage social interaction. That's why, the kind of tasks and activities requested to students become the trigger factor to fuel higher mental processes. When scaffolded instructions are provided during the first lessons, learning is more likely to occur not only because students feel affectively supported, but also because each scaffold guides the brain towards a comprehensive understanding of the input in use. In addition, teachers can also motivate peer-work in order to create the chances for them to exchange personal insights or strategies they employ to better reach the class goals and hopefully, sort out problems cooperatively. According to Nguyen (2013), pair work and group work have proven to support the foundations of the Socio-cultural Theory, since it has been demonstrated that collaborative learning is mainly constructed through interactions.

In accordance with Vygotsky's Socio-cultural Theory findings, teachers should be constantly interacting with their learners at different levels. One way to do so is to assign homework with challenging input tasks to be carried out individually in order to find out what students' progress is and keep high performance expectations for the course. Teachers' main aim is to both provide students with a bunch of opportunities to practice and indeed, generate appropriate feedback that leads to excellent learning outcomes. In regard to these challenging tasks, Albaiz (2016) suggests the use of e-portfolios, 


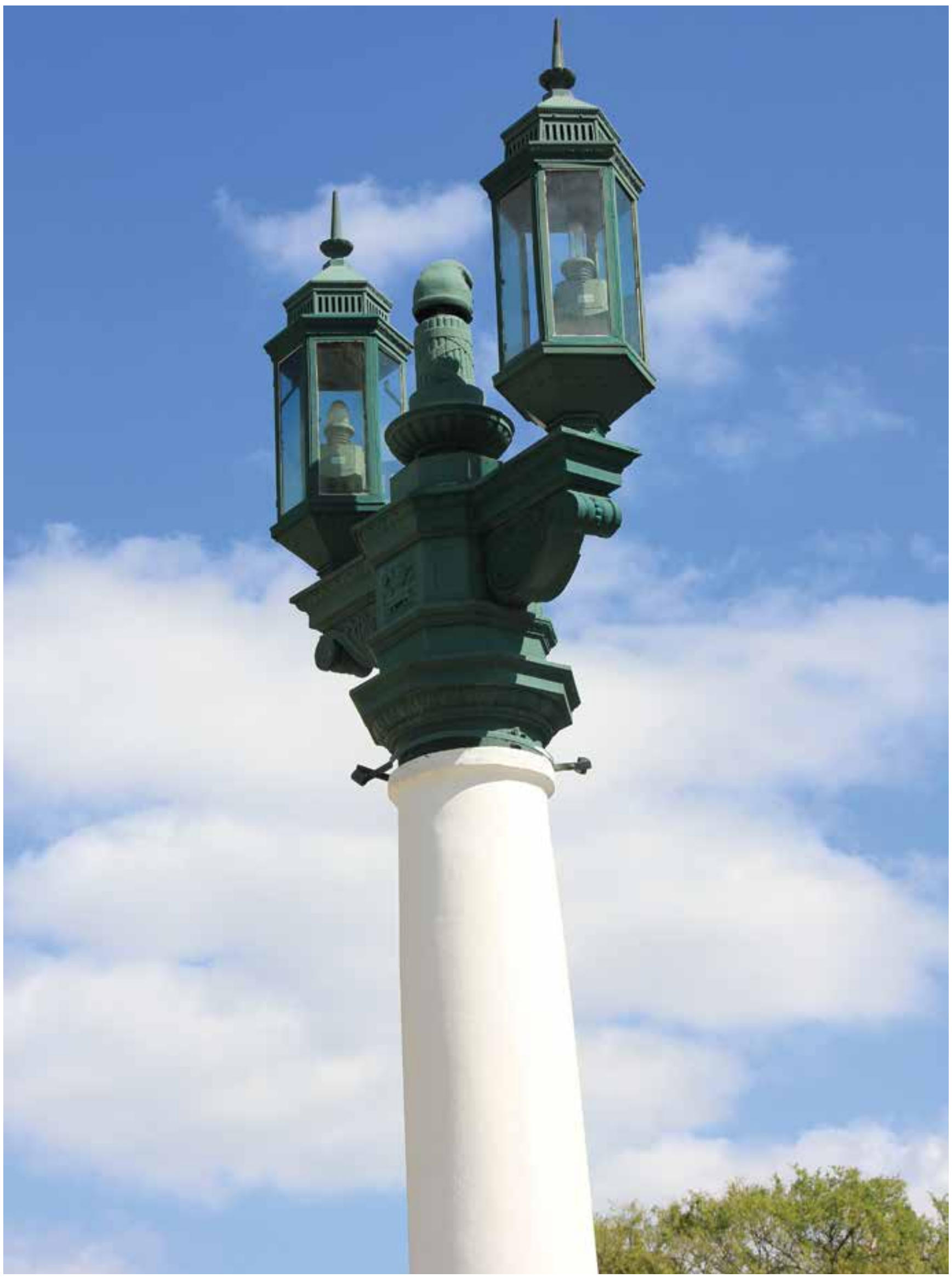


which promote a constant online reflection around the most effective processes towards SLA where second language learners can share data with others and use scaffolding techniques to improve skills helping each other.

As a matter of fact, it has also been demonstrated the positive effects of challenging input on students who show high cognitive functioning as well as an effective use of scaffolding techniques. When analyzing higher order mental processes such as defining, describing, comparing, classifying, sequencing, linking causes and effects, establishing analogies and identifying whole to part relationships, there exists a new revolutionary learning tool called Thinking Maps teachers may implement. This model consists of visual patterns aimed at matching a variety of cognitive skills and enhancing a long term learning experience.

\section{SIOP - A New Approach in SLA}

\section{Definition}

At this point, it is evident that what teachers should always have in mind is the value of scaffolding to power and guarantee students' ZPD. In fact, there is a new teaching method called Sheltered Instruction Observation Proto$\mathrm{col}-\mathrm{SIOP}$, which is aimed at foreigners whose mother tongue is not English and who want to join an English-speaking school with other native students. This innovative teaching model was introduced by Jana Echeverria, Mary Ellen Vogt \& Deborah Short, who worked collaboratively on both the US west and east coast, in order to come up with an observation protocol based on what they had seen in classrooms all around the country. Both Echeverria \& Vogt (1996) started analyzing the effectiveness of the strategies used by teachers responsible of general instruction, who progressively were faced with the challenge of teaching immigrant students whose English language proficiency was at an emergency stage. They noticed how poorly prepared they were to assist those chil- dren, whose numbers started to grow since the mid-1990's into learning content through a language they were not even ready to speak. Due to this cultural and linguistic need, both authors began the process of analyzing how the Sheltered Instruction and the Content based Instruction, commonly known as $\mathrm{CBI}$, could be merged into a new teaching perspective that took into consideration having English Learners achieve both content and language goals. After conducting a comprehensive research and field testing all the strategies within a great variety of classrooms pre-K-12 from 1995 to 2000, Echeverria \& Vogt (1996) ended up with thirty features to describe in detail what a meaningful lesson should look like and they put them together to build what is known nowadays as the SIOP Model. They truly believed in that English learners need to be provided with the necessary support to learn any content area through English systematically, without waiting first to develop high language proficiency levels.

\section{Justification}

This empirically validated model of instruction is actually back up by Spezzini who went beyond the interpretation of the protocol to categorize the three most important moments within the SIOP: Spezzini (2013) assures that a lesson is divided into the preparation stage, the instruction stage, and the review stage. Furthermore, within the instruction moment, English teachers are invited to put into practice six different features such as Building Background, Comprehensible Input, Strategies, Interaction, Application and Lesson Delivery. According to the Institute of Educational Sciences (2013), this innovative framework for planning, delivering and assessing instruction in content areas for second language learners does allow teachers to modify their language progressively in order to make it more comprehensible. What this means is that when teachers are likely to put themselves in their students' shoes and empathetically adjust to their level of competence, they are able to negotiate meaning, gain their 


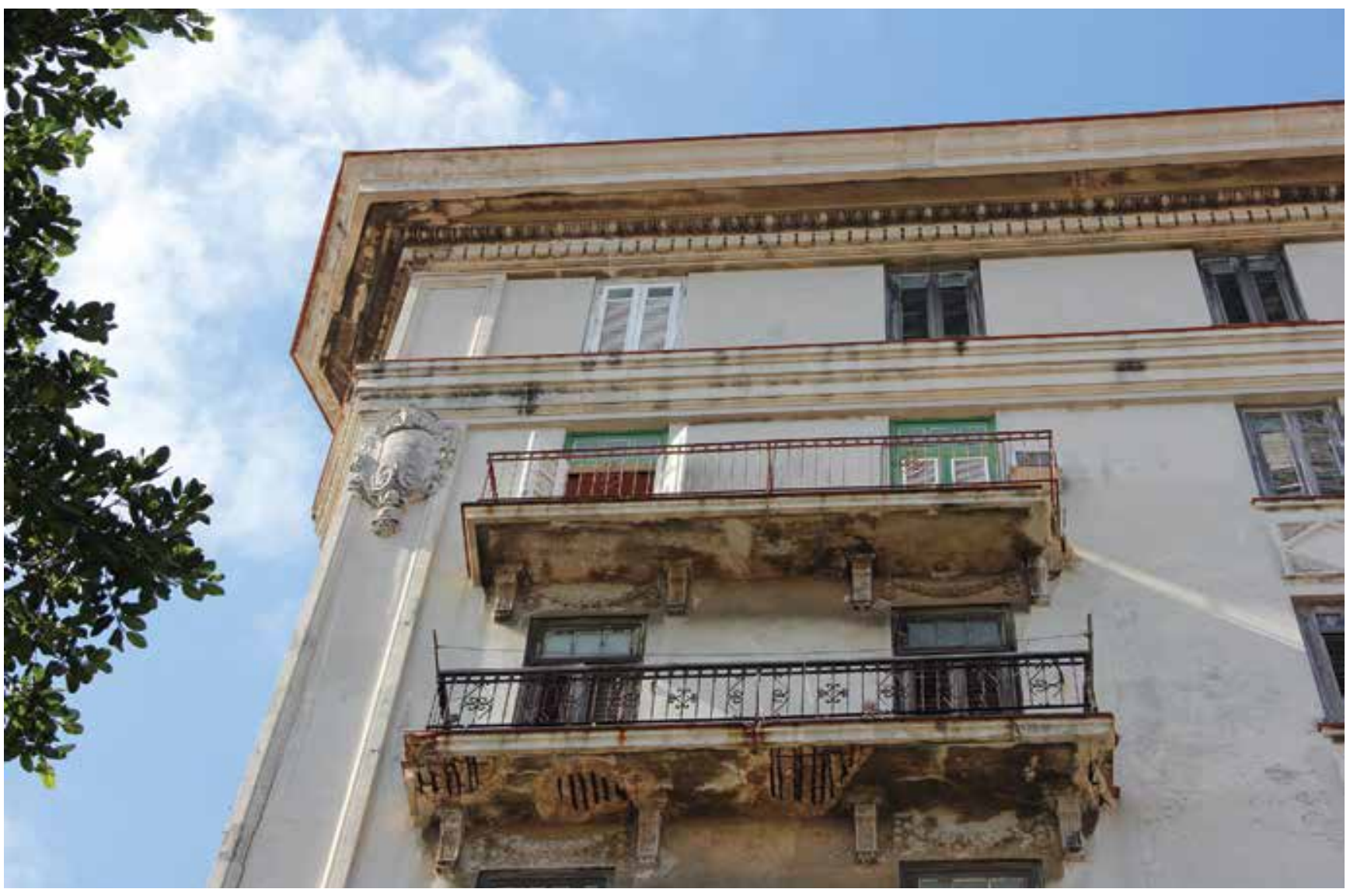

trust and eventually, lead them to rewarding learning experiences.

\section{Application}

In order to begin with the implementation of the SIOP, which has proven successful within US territories and several other countries where English is not the main language of instruction, it is absolutely necessary to identify clear content objectives as well as language objectives (Powers, 2006). First, teachers are entitled to recognize the most relevant concepts to teach and select the most effective materials, adaptations and activities to carry out throughout the lesson.

Second, teachers are expected to make connections to students' prior knowledge and past experiences so that they can incorporate the new vocabulary into their existing thoughts. One of the strategies called "List-group-label" suggests that students can brainstorm as many ideas as possible on slips of paper and then, classify them into categories grouping those with clear similarities; this exercise helps their brain retain the information in a more accurate way so they can start the instruction stage smoothly.

Third, after teachers have developed their lessons based on their students' common underlying proficiency, they are invited to teach and give clear directions for academic tasks by means of appropriate speech, body language, visuals, hands-on activities and demonstrations. According to Jim Cummins (1979), there is a great difference between working on Basic Interpersonal Communication Skills -BICS, which are used for everyday life interactions and acquired during the first two years of second language learning; and reaching Cognitive Academic Language Proficiency -CALP, which appears mainly in formal academic settings after five years of real exposure to the language in school, college or professional work. 
Fourth, teachers need to critically think about how to raise students' thinking levels and the best way to target that goal is by means of higher-order questioning. It has been shown that when students are led through different strategies to foster not only knowledge, comprehension and application skills, but also analysis, synthesis and evaluation, they gain more confidence to compare and contrast, attain problem solving, and perform self/peer assessment (Bloom, 1956).

Among the SIOP strategies, there are three which would be imperative to include in current teaching practices: a). Success through Scaffolding, in which language teachers must be aware of the importance of leading students towards independence, where little by little they can start developing language skills without the constant intervention of the teacher. However, this will not happen overnight. Teachers should have in mind that foreign language learning takes time and that certain strategies such as teaching concepts from general to specific (explicit instruction), letting students work in groups (cooperative approach) and allowing them to think about their own learning process (metacognition) will definitely help students achieve independence, understand what better works for them and make their learning more effective. b). Alternate Materials, which teachers can incorporate in the shape of any kind of visual resources, audio and video aids, literature, realia, field trips and even online resources to their classes. For instance, instead of bringing pictures of food and drinks to teach vocabulary, students may be encouraged to make a real sandwich and use quantifiers and imperative forms while describing how to make it. Jarvis \& Krashen (2014) accordingly believe in the power of technology in SLA; both authors assure that devices such as laptops, tablets and smartphones are certainly changing the way we interact among each other since the subconscious processes we establish end up being more prevailing than conscious learning. Additionally, they explain that when a second language is learned mechanically by teaching only a set of rules and exceptions for rote memorization, students are limited to constantly monitor what they say and write, without letting themselves some freedom to develop abilities naturally and spontaneously. Smartphones have become a great non-pedagogical resource for second language input, interactions and information as it was demonstrated in a study carried out with 120 Thai students learning English in their home country. The vast majority of the participants claimed to use their mobile phones at a higher frequency than ever before due to the fluent amounts of data that can be easily accessed at any time and any place as well as the endless opportunities for implicit input through social networks. Likewise in another research study, the authors found that second language learners are using English more often for personal and academic purposes than their mother tongue: $86 \%$ of the second language learners interviewed assured they were using English (the target language) even before moving to the UK to officially start their studies (Jarvis \& Krashen, 2014). c). Planning through Flow Charts, which help teachers keep a close control of what, how and when to teach and assess students (scope and sequence) by organizing content and language objectives for about two weeks. Therefore, if foreign language teachers start programming carefully their time and class objectives, language learning will be more efficient.

Fifth, for a successful SIOP lesson, teachers need to make sure to create a non-threatening environment for interactions and discussion to take place. When students are encouraged to work cooperatively, they can easily make a bridge between the oral and written language and use all the opportunities given to adjust it just beyond their individual level of production. In addition, frequent interactions in our classrooms in the shape of whole class, small group or pair work can promote the develop- 


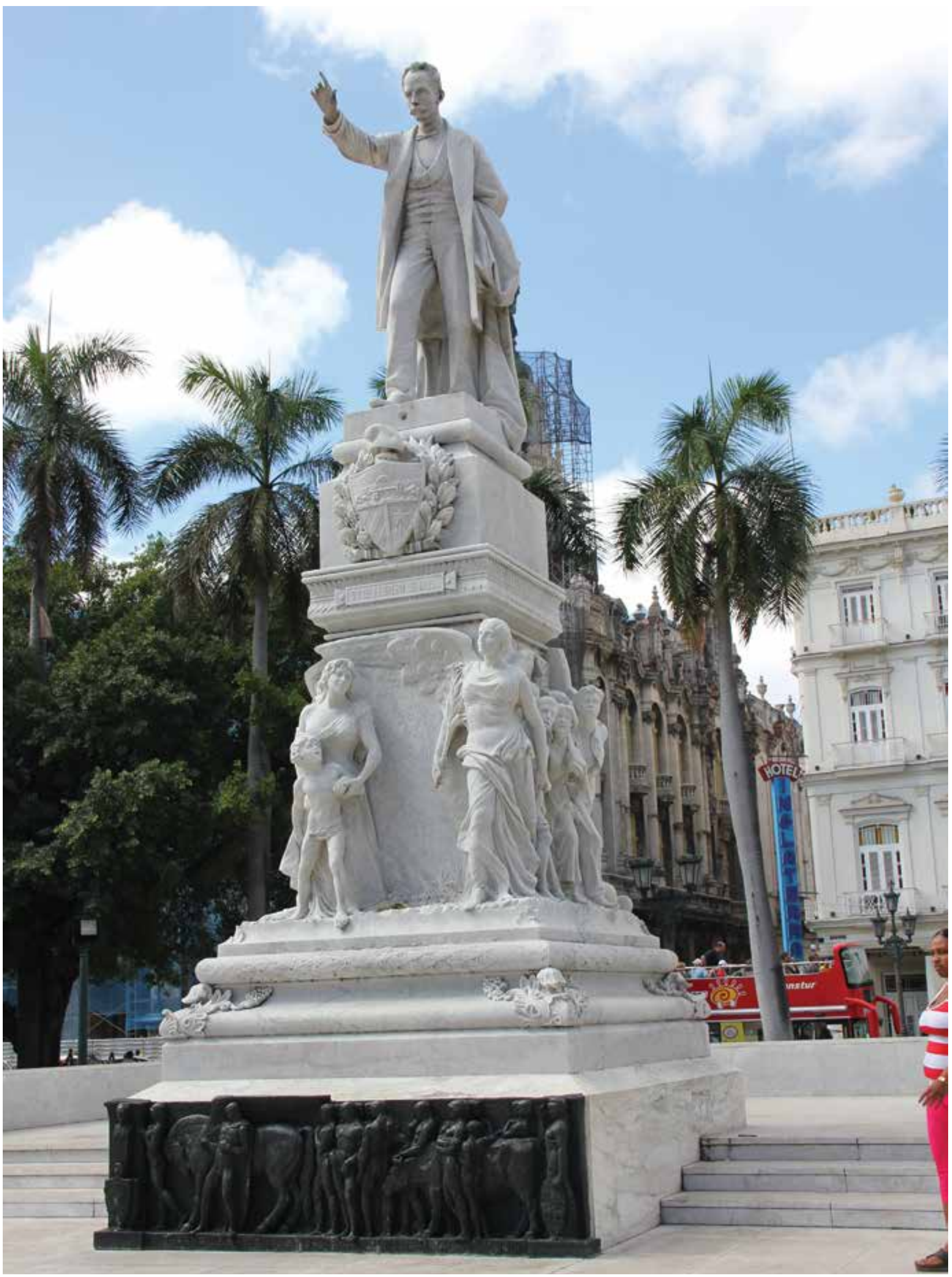


ment of social skills that indeed, are reinforced throughout Vygotsky's Socio-cultural Theory.

Sixth, teachers need to provide students with the most suitable practice and application opportunities which normally follow the model-create-share pattern. Moreover, while performing listening, reading, writing and speaking tasks, students are implicitly developing language skills and mastering content and vocabulary. According to Beers (2009), the use of graphic organizers can result on higher retention and better information processing in students' brains. Similarly, Beverly \& Michele (2015) support the idea of Dale's Cone of Experience, in which learning by doing produces the highest powers of recall since students can actually remember up to $90 \%$ of what they do, compared to $10 \%$ of retention when they just read.

Seventh, when teachers finally deliver their lesson, it is certainly necessary to link directly both content and language objectives; when what is done in class makes sense to students, it is possible to attain up to $90 \%$ of student engagement by using appropriate pacing as well. Finally, the last stage in the SIOP model is focused on reviewing vocabulary and concepts and providing well-rounded feedback before actuaIly assessing students' understanding. Rubrics to evaluate students' themselves, peer review and teacher assessment have shown great benefits towards a successful SIOP lesson.

\section{Conclusion}

All in all, it is undeniable the impact that the Socio-Cultural Theory has had on SLA methodologies during the last decades. Second language teachers from all around the globe have become aware of the key role of comprehensible input in their lessons as well as the positive influence of interaction with different group configurations and class objectives among their students. Likewise, what ESL teachers have to remember is that all learners are different from each other and that language learning depends primarily on their own motivation and personal learning interests. At that point, teacher intervention and well-planned lessons are essential and so the SIOP certainly provides great ideas to lead students to successful language learning. This innovative model of instruction has been lately highlighted as one of the most comprehensive and highly effective approaches, which allows teachers to incorporate content by means of a second language that is systematically and consistently reinforced throughout each stage of the lesson, from the preparation and instruction to the review and assessment. In the light of this premise, SIOP is ultimately a great model to gradually implement at all levels and at all subjects that merges comprehensible input and interaction as cornerstone features within the SLA theoretical and practical framework.

\section{References}

Albaiz, T. (2016). The Pearl Side of Online Portfolios: A Descriptive Study on the Rich Experience of Using Pearl trees by Master Students of Teaching English as a Foreign Language. TOJET: The Turkish Online Journal of Educational Technology, 15(1), 136-140. Retrieved from http://www.tojet.net/volumes/v15i1.pdf

Bear, D.R., Helman, L., Templeton, S., Invernizzi, M. \& Johnston, F. (2007). Words their way with English learners: Word study for phonics, vocabulary, and spelling instruction. Upper Saddle River, NJ: Pearson Education.

Beers, K. (2009). Graphic organizers are tools that help your brain think. Holt Interactive Graphic Organizers. Retrieved from http://my.hrw.com/nsmedia/intgos/html/igo.htm

Benati, A. (2016). Input manipulation, enhancement and processing: Theoretical views and empirical research. Studies in Second Language Learning and Teaching. University of Greenwich, UK. Pressto 6(1), 65-88. Retrieved from http://pressto.amu.edu.pl/index.php/ssllt/article/view/5294

Beverly, D. \& Michele, S. (2015). Applying Dale's Cone of Experience to increase learning and retention: A study of student learning in a foundational leadership course. QScience Proceedings: Engineering Leaders Conference, 2014, 6. Retrieved from: http://www.qscience.com/ doi/10.5339/qproc.2015.elc2014.6

CAL. (2017). What is the SIOP Model? Retrieved from the Center for Applied Linguistics website. http://www.cal.org/ siop/

Celic, C. (2009). A Complete Guide to Literacy, Content-Area, and Language Instruction. NY: Heinemann.

Donato, R. (1994). Collective scaffolding in second language learning. In: Lantolf, J. P. (Ed.). Vygotskian approaches 
to second language research (pp. 33-56). London: Ablex Publishing.

Donato, R. (2000). Sociocultural contributions to understanding the foreign and second language classroom. In: Lantolf, J. P. (Ed.). Sociocultural theory and second language learning. Oxford University Press.

Echevarria, J., Vogt, ME. \& Short, D. (2004). Making content comprehensible for English learners: the SIOP model. (2nd ed.). Boston, MA: Pearson Education.

Ellis, R., (2000). Task-based research and language pedagogy. Language Teaching Research, 4(3), 193-220.

Ellis, R., Tanaka, Y., y Yamazaki, A. (1994). Classroom interaction comprehension and the acquisition of $\mathrm{L} 2$ word meanings. Language Learning, 44, 449-49.

Ferlazzo, L., \& Hull Sypnies, K. (2012). The ESL / ELL Teacher's Survival Guide: Ready-to-Use Strategies, Tools, and Activities for Teaching English Language Learners of All Levels. NY: Jossey-Bass.

Freeman, Y., \& Freeman, D. (2009). Academic language for English language learners and struggling readers: How to help students succeed across content areas. Portsmouth $\mathrm{NH}$ : Heinemann.

Gass, S. (1997). Input and Interaction. Retrieved from http:// w3.coh.arizona.edu/classes/lwaugh/slat596/gass_input.pdf

Gee, S., (1997). Teaching writing: a genre-based approach. In: Fulcher, G. (Ed.). Writing in English language classroom. Hertfordshire: Prentice Hall Europe ELT.

Gibbons, P. (2002). Scaffolding language, scaffolding learning teaching second language learners in the mainstream classroom. NH: Heinemann, Portsmouth.

Haynes, J. (2004). SIOP: Making Content Comprehensible for ELLs. Retrieved from http://www.everythingesl.net/inservices/using_siop_model_08621.php.php

Herrera, G.S., \& Murray, K. G. (2011). Mastering ESL and Bilingual Methods. Upper Saddle River, NJ: Pearson Education.

Horowitz, D. (1986). Process not product: less than meets the eye. TESOL Quarterly, 20(1), 445-462.

Hyerle, D., \& Yeager, C. (2007). A language for learning: Thinking maps Incorporated, 1-20.

Jarvis, H., \& Krashen, S. (2014). Is CALL Obsolete? Language Acquisition and Language Learning Revisited in a Digital Age. The Electronic Journal for English as a Second Language, 17(4), 1-6. Retrieved from http://www.tesl-ej.org/ wordpress/issues/volume17/ej68/ej68a1/

Lipson, M., \& Wixson, K. (2003). Assessment and instruction of reading and writing difficulty: An interactive approach (4th Ed.). Boston: Allyn \& Bacon.

Min, G. (2006). Vygotsky's Sociocultural Theory and the Role of Input and Output in Second Language Acquisition. Wuhan University. CELEA Journal, 68, 29.

Moss, D. (2003). Second Language Acquisition in Adults: From Research to Practice. National Center for ESL Literacy Education, Georgetown University. Retrieved from http://www.cal.org/caela/esl_resources/digests/SLA. html

Navracsics, J. (2014). Input or intimacy. Studies in Second Language Learning and Teaching. University of Panno- nia, Hungary, 4(3), 485-506. Retrieved from https://www. researchgate.net/publication/287556786_Input_or_intimacy

Nguyen, M. (2013). EFL Students' Reflections on Peer Scaffolding in Making a Collaborative Oral Presentation. English Language Teaching. Canadian Center of Science and Education, 6(4), 64-73. Retrieved from http://www. ccsenet.org/journal/index.php/elt/article/view/25563

Nowbakht, M. (2015). The Comparative Effects of Comprehensible Input, Output and Corrective Feedback on the Receptive Acquisition of L2 Vocabulary Items. Advances in Language and Literary Studies, 6(4), 103-114. Australian International Academic Centre. Retrieved from http://www.journals.aiac.org.au/index.php/alls/article/ view/1624

Peregoy, S. (2012). Reading, writing, and learning in ESL. A resource book for K-12 teachers. NY: Pearson.

Powers, K. (2006). School reform and standards-based education: An instructional model for English Language Learners. Journal of Educational Research, 99(4), 195-211.

Readence, J.E., Bean, T. W., \& Baldwin, R. S. (2004). Content area literacy: An integrated approach (8th Ed.) Dubuque, IA: Kendall/Hunt Publishing Company.

Reiss, J. (2012). 120 Content Strategies for English Language Learners (2nd Edition). New York: Allyn \& Bacon.

Salazar, P. (1996). Comprehensible input and learning outcomes. Jornades de Foment de la Investigació. Universitat Jaume. Retrieved from www.uji.es/bin/publ/edicions/ jfi2/compren.pdf

SIOP. (2017). Retrieved from The SIOP Institute Website http://www.siopinstitute.net/about.html

Spezzini, S. (2013). Enhancing Language for Specific Purposes through Interactive, Peer-to-Peer Oral Techniques. Scholarship and Teaching on Languages for Specific Purposes. University of Alabama, Birmingham. Retrieved from http://static.squarespace.com/static/513fb99fe 4 b0878d799ba12c/t/ 520 a913de4b0f3bf53bb700e/1376424253563/ Enhancing+LSP+Through+Peer-to-Peer+Techniques+ by+Susan+Seay,+Susan+Spezzini+\%26+Julia+Austin+. pdf

Spezzini, S., La Cross, L., \& Austin, J. (2013). A doctoral student's shift from modified AAVE to Standard English: Evidence for taking a Language for Specific Purposes (LSP) approach. In L. Sánchez-López (Ed.). Scholarship and Teaching of Languages for Specific Purposes. ISBN 978-0-9860107-0-5.

Spezzini, S. (2010). Effects of visual analogies on learner outcomes: Bridging from the known to the unknown. International Journal on the Scholarship of Teaching and Learning, 4(2), 1-30. http://academics.georgiasouthern. edu/ijsotl/v4n2.html

Spezzini, S. (2010). Children were punished: Not for what they said but for what their teachers heard. Childhood Education, 86(3), 130-131. http://images.magnetmail. net/images/clients/ACEl/attach/issues.pdf

Spezzini, S. (2009). Fostering language in English language learners through grammaring and IPOTs. Focus on Teacher Education, 9(3), 5-6. http://acei.org/wp-content/ uploads/Spr09Teach.pdf 
Spezzini, S. (2009). Fostering language in English language learners through grammaring and IPOTs. Focus on Teacher Education, 9(3), 5-6. http://acei.org/wp-content/ uploads/Spr09Teach.pdf

Spezzini, S. (2006). Helping English language learners with pronunciation. Focus on Teacher Education, 7(1), 3-4.

Spezzini, S. (2004). English immersion in Paraguay: Individual and sociocultural dimensions of language learning and use. International Journal of Bilingual Education and Bilingualism, 7(5), 412-31. http://www.informaworld. com/smpp/title $\sim \mathrm{db}=$ all $\sim$ content $=\mathrm{g} 908067275$

Spezzini, S., \& Oxford, R. (1998). Perspectives of pre-service foreign language teachers. System 26(1), 65-76.

Tharp, R., \& Gallimore, R. (1988). Rousing minds to life. Cambridge: Cambridge University Press.

Turuk, M. (2008). The relevance and implications of Vygotsky's sociocultural theory in the second language classroom. ARECLS, 5, 244-262. Retrieved from https:// research.ncl.ac.uk/ARECLS/volume_5/turuk_vol5.pdf

U.S. Department of Education, Institute of Education Sciences. (2013). What Works Clearinghouse. English Language Learners intervention report. Sheltered Instruction Observation Protocol ${ }^{\circledR}\left(S I O P^{\oplus}\right)$. Retrieved from http:// whatworks.ed.gov
Van Der Stuyf, R. (2002). Scaffolding as a Teaching Strategy. Adolescent Learning and Development, Section 0500a.

Vogt, M. E., \& Echeverria, J. (1996). 99 Ideas and Activities for Teaching English Learners with the SIOP Model. Pearson Education Limited.

Vogt, M.E. (2000). Active learning in the content areas. In M. McLaughlin \& M.E. Vogt. Creativity and innovation in content area teaching. Norwood, MA: Christopher-Gordon Publishers.

Vygotsky, L. (1978). Mind and Society: The Development of Higher Psychological Processes. (M. Cole, V. John-Steiner, S. Scribner, \& E. Souberman, Eds. and Trans.). Cambridge, MA: Harvard University Press.

Yi, B., \& Sun, Z. (2013). An Empirical Study of the Effectiveness of Negotiation of Meaning in L2 Vocabulary Acquisition of Chinese Learners of English. English Language Teaching, 6(10), 120-131. Canadian Center of Science and Education. Retrieved from http://files.eric.ed.gov/ fulltext/EJ1077092.pdf 